\title{
EDITORIAL
}

\section{SOBRE A PROFISSIONALIZAÇÃO DE TRABALHADORES DE SAÚDE SEM QUALIFICAÇÃO ESPECÍFICA}

Há longa data as instituiçőes de saúde no Brasil incorporam trabalhadores de saúde sem a qualificação técnico - profissional requerida e necessária para a execução de açōes e procedimentos que lhes são atribuídos. Tal prática usual e fortemente consolidada, tanto nos serviços de saúde públicos comos privados (na rede hospitalar e ambulatorial), gerou, como não poderia deixar de acontecer, uma situação para a qual não há justificativa que sustente sua manutenção, quando se pretende melhorar o nivel e padrão de qualidade da assistência à saúde no País, assim como as condiçōes e as relaçőes de trabalho no sistema de saúde. No entanto, setores e segmentos da sociedade, entre estes alguns govemantes, dirigentes e representantes políticos, profissionais de saúde e empresários do setor, usam das diferenças regionais que marcam o País; do número insuficiente de escolas profissionalizantes do nivel médio; do reduzido número de egressos das escolas existentes e da concentração regional de profissionais técnicos de saúde, para sustentarem a manutenção desta prática.

Seguramente, estes são dados irrefutáveis da nossa realidade e que por isso mesmo devem ser considerados quando são propostas e definidas as políticas sociais e a organização e funcionamento dos serviços de saúde. Mas, considerá-los, não significa usá-los como parâmetros e justificativas de uma prática cujo resultado é o que esse tem hoje: grande parte dos serviços que são realizados no sistema de saúde está sob a responsabilidade de trabalhadores que não foram preparados e que não estão qualificados para a especificidade técnica exigida pelo trabalho que fazem. Para a maioria da sociedade, para os usuários em geral, a afirmativa de que grande parte dos serviços de saúde está a cargo desses trabalhadores, pode parecer um falseamento da realidade, mesmo porque, o fato da assistência à saúde estar sendo majoritariamente realizada por năo-profissionais não é clara e amplamente explicitada para os usuários dos serviços. O que confere absoluta veracidade a esta afirmativa é termos a certeza que, exceto nas áreas do trabalho do médico, do odontólogo e do psicólogo, as demais (enfermagem, nutrição, farmácia, serviços de hematologia, análises clínicas, apoio diagnóstico em geral, arquivos) contam com um número expressivo de trabalhadores sem a devida formação. Esta situação é de tal sorte grave, que exige uma ação coletiva e combinada de todos que estão envolvidos nela, e que em última instância, são os responsáveis pelas conseqüências técnicas, éticas e sociais que dela advêm.

Para alguns, a proposta se resume na ampliação de escolas e vagas, que assegurem a educação geral e a criação de cursos profissionalizantes que privilegiem as habilitações de saúde do nível médio. Sem dúvida, é imprescindivel que isto ocorra. No entanto, esta é uma proposta inoportuna em relação à qualificação daqueles que já estão inseridos na produção de serviços de saúde. Ela cumprirá o papel de gerar os futuros profissionais de saúde de nível médio que ingressarão no mercado. Seu impacto nos serviços de saúde só poderá ser esperado a médio e longo prazos . A situação que se tem hoje nos serviços de saúde exige que o sistema de saúde público e privado - implementem programas de profissionalização dos seus trabalhadores sem qualificaçăo especificas que foram (e continuam sendo) incorporados nos serviços. É preciso salientar que muitos deles não possuem nem $1^{\circ}$ grau de escolaridade, o que toma a situação mais grave. As propostas que pretendem resolver o problema impedindo-os (até judicialmente) de trabalhar e exigindo demissões sumárias, têm sido apresentadas. Infelizmente, tais propostas só têm servido para adiar uma possível solução e aumentar o número destes trabalhadores no setor saúde. $O$ que precisa ser concretizado é um programa efetivo de profissionalização para estes trabalhadores que contemple: 
- o conteúdo técnico exigido para cada habilitação específica;

- A adoção de métodos e metodologias que permitam ao trabalhador entrar no processo de formação sem afastar-se do seu serviço e nem tampouco cumprir jomada de trabalho adicional;

- o enquadramento, dos que concluirem o processo, nos planos de cargos, carreira e salários.

Uma proposta que atenda a estes eixos não está revestida de nenhuma ardilosa trama ou magia. Ela é viável e vem sendo concretizada em alguns Estados, em que pesem os parcos recursos (físicos, humanos, financeiros) que têm recebido dos organismos e instituições de saúde e de educação - ambos diretamente responsáveis pela situação. As diretrizes para a sua implementação estão reunidas em documento do Ministério da Saúde / Coordenação Geral de Recursos Humanos para o SUS / divulgado no início de 1993) intitulado Diretrizes para a Profissionalizaçăo de Trabalhadores de Saúde sem Qualificaçăo Especifica. Para sua formulação, contou-se com a participação da OPS, de representantes do CONASS, CONASEMS, órgãos de classe, como de técnicos do Ministério de Saúde e Educação. Inicialmente, as experiências que viabilizaram tal proposta, tomaram a área de enfermagem como prioridade e foram elas umas das referências para a definição das diretrizes constantes do Documento referido. Hoje, os programas que estão sendo executados abrangem as habilitaçס̃es de outras áreas como previa o projeto inicial. Este Programa, como está definido, destina-se exclusivamente às pessoas que já estão trabalhando nos serviços de saúde e exige que o serviço de saúde se articule formalmente com o setor de Educação. Garante-se, assim, entre outras vantagens, a utilização dos recursos humanos profissionais lotados no sistema de saúde com instrutores / professores; das unidades de prestação de assistência, onde o trabalhador já está inserido, como campo de prática; e o cumprimento das determinaçőes do sistema educacional no que se refere à organização, estruturação, administração e funcionamento do programa. Um ponto tem sido motivo de resistências a esta proposta: refere-se ao fato de que o Programa, em total consonåncia com o que prevêm as leis educacionais, é firmemente dirigido à qualificação técnica dos que já trabalham e não exclui do processo aqueles que não concluíram o grau de escolaridade da educação geral. Estes, ao concluírem o currículo técnico definido, recebem um certificado sem direito à continuaçăo de estudos. Isto significa que esta pessoa concluiu o conteúdo teórico e prático de uma determinada habilitaçăo de nível médio, porém não completou seus estudos em termos da educaçăo geral , que poderão ser concluídos posteriormente, quando então ser-lhe-á assegurado o diploma.

O que significa isto? Significa que, frente a uma situação alarmante, onde numerosos trabalhadores de saúde não têm qualificação profissional e alguns destes não têm a escolarizaçăo básica (não porque fugiram ou se negaram a ela, mas porque foram excluídos da Escola), optou-se por um programa que, em um primeiro momento, cumpre a função de conferir a qualificação técnicoprofissional específica por um dever ético e técnico com os trabalhadores que não a têm; com aqueles que eles atendem; e com a organização dos serviços de saúde na perspectiva de, realmente, termos condições de produzir melhoria na assistência de saúde. É inegável o direito de todos a um trabalho digno. Sabemos que este direito está sendo seqüestrado de grande parte dos brasileiros. O Programa, seguramente, não resolve nem compensa o seqüestro deste direito. Propõe somente diminuir o espaço da expropriação que vem sendo imposta à parte dos trabalhadores e aos usuários dos serviços de saúde. 